\title{
Report（報 告）
}

北アルプス蝶ヶ岳の稜線でオバシギを観察

小島 桂*・小島治好**

\section{A Snipe, the Great Knot (Calidris tenuirostris), at the Ridge of Northern Alps, Tyougatake}

\author{
Katsura Kojima* and Yoshiharu Kojima**
}

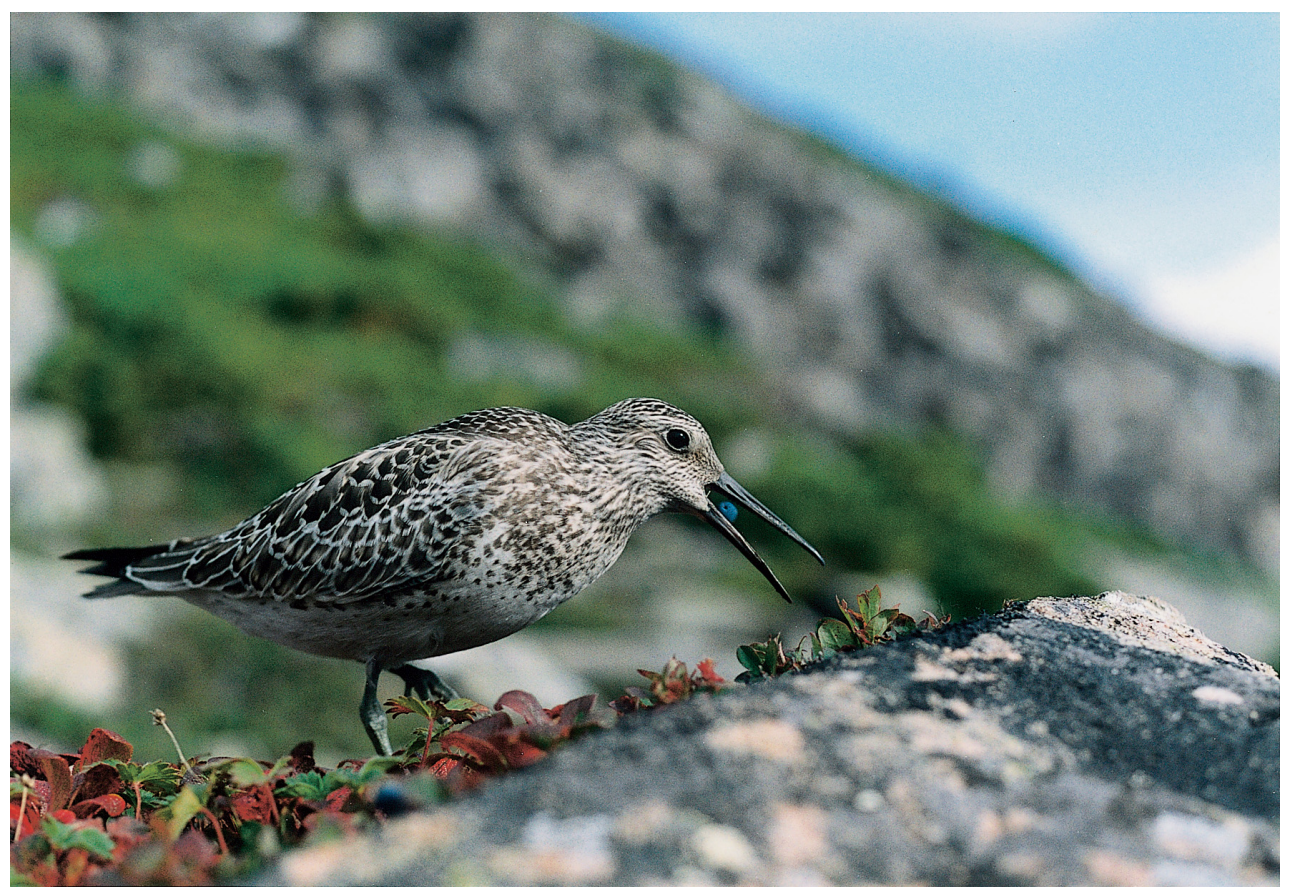

図 1.クロマメノキの実を食べるオバシギ Calidris tenuirostris.

Fig. 1. A Great Knot, Calidris tenuirostris, eating a berry of the alpine plant Vaccinium uliginosum.

Received 15 April 2005.

* 独立行政法人農業生物資源研究所， $=305-8602$ 茨城県つくば市観音台 2-1-2.

** 干381-0025 長野県長野市北長池 1198-1.

* National Institute of Agrobiological Sciences, 2-1-2 Kan-nondai, Tsukuba, Ibaraki 305-8602, Japan.

** 1198-1, Kita-nagaike, Nagano, Nagano 381-0025, Japan. 
1997 年 9 月 9 日, 午後 3 時頃, 長野県南安晴郡安晴村, 蝶ヶ岳ヒュッテから約 $600 \mathrm{~m}$ 北の稜 線（標高約 2,600 m) で, クロマメノキVaccinium uliginosum の実を豚ばんでいるオバシギ Calidris tenuirostris を写真撮影したので報告する（図 1)。この鳥は嘴が長めで黒く，胸に顕著な黒 斑があり, 背・肩羽・雨覆が黒褐色で羽縁が白いことから, 幼羽のオバシギである。シギ・チ ドリ類のわが国の高山帯での報告は珍しいが，彼らが繁殖しているッンドラの環境は，おそら くこのようなものであろう。なお，この鳥が高山まで吹き上げられるような，9月9日以前の台 風などの記録は気象庁の記録を見る限り見当たらなかった。

写真から種と齢を同定していただいた山階鳥類研究所の茂田良光氏に深く感謝する。 